\title{
フランジ厚さを変化させた天然 THE TENSILE TESTS OF NATURAL ゴム系積層ゴムの引張試験 \\ RUBEER BEARINGS FOCUSED ON THE EFFECT OF THE STEEL FRANGE PLATES
}

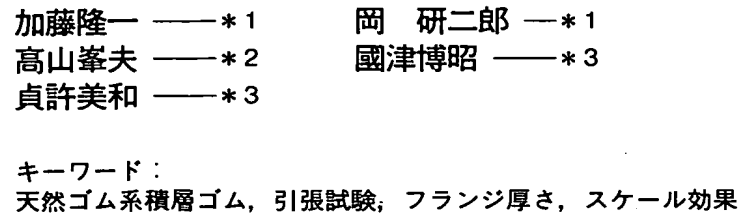

\section{岡 研二郎 $-* 1$}

國津博昭 — $* 3$

Natural rubber bearings, Tensile tests, Steel flange plate, Scale effect

\section{Ryuichi KATO - *1 \\ Mineo TAKAYAMA $-* 2$ \\ Miwa SADAMOTO $-* 3$}

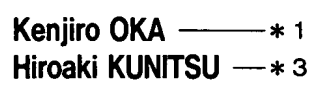

In this study, tensile tests for the Natural Rubber Bearings were performed to investigate the vertical and horizontal restoring force characteristics and the scale effect in small extensional region, as well as the influence of the thickness of the flange plate. From the results of tensile tests, the extensional stiffness was sensitive to the flange plate thickness and scale rule was effective at small extensional region. The deformation of the flange plate subjected to tensile load can be expressed by the simple theoretical equation. Consequently the behavior of rubber bearings under tensile load can be evaluated including the deformation of the flange plate.
1.はじめに

兵庫県南部地震により多大な人的・物的被害をもたらした阪神 淡路大震災以降、免震構造は積層ゴムを中心とし、官庁や病院、共 同住宅をはじめとする建築物に適用され、日本では、既に 800 棟以 上の免震建物が建設されている。最近では、高層建築や戸建住宅、 中間階免震などにも積層ゴムあるいはそれ以外の免震装置を適用 する事例も現れている。

近年では高層建築物への適用も増加してきている。高層建筑物 が地震を受けた場合、外側の柱には引き抜き力が発生作用する可 能性があるとの報告 ${ }^{1}$ がある。また、実際にー $1 \mathrm{~N} / \mathrm{mm}^{2}$ 程度の引張面 圧を想定して、建設された構造物の事例もある。

積層ゴムの引張について、Gent ${ }^{2}{ }^{2}$ は、天然ゴムのゴムブロックについ て、引張試験を実施し、ゴム材料のヤング率の約 $0.5 \sim 1.0$ 倍に相当 する応力度の範囲で内部クラックであるボイドが発生すること示した。 高山 ${ }^{3)}$ は天然ゴム系積層ゴムについて、単純引張試験に関して破断 まで、全ゴム厚さの 3 倍程度の変形能力を確認しているが、引張が作 用する場合でも、ヤング率程度以下の応力とすべきであるとの見解を 述べている。また、大鳥 ${ }^{4)}$ は、天然ゴム系積層ゴムについて、引張許 容応力の設定法について提案し、許容応力はー $1 \mathrm{~N} / \mathrm{mm}^{2}$ 程度であ るとの結果を報告している。

そこで、本報告では、天然ゴム系積層ゴムについて、ー $1 \mathrm{~N} / \mathrm{mm}^{2}$ 程 度の微小引張面圧が作用したときの、(1)微小引張領域での積層 ゴムの鉛直・水平復元力特性、(2)微小引張領域での積層ゴムのスケ 一ル効果および(3)引張特性におけるフランジ厚さの影響について調 べることを目的として(a)所定のせん断ひずみを与えた状態で、鉛直

\footnotetext{
-1 令数化工㑣産業機器事業部

(厂712-8555 倉敖市連島町矢柄四の町 4630)

*2 福岡大学工学部建築学科 助教授. 工博

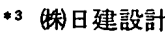

方向に繰り返し引張圧縮変形を与えるオフセット引張圧縮試験と(b) 鈶直方向に所定の引張変形を与えた状態で、水平方向に繰り返し せん断変形を与える引張せん断試験を行った。フランジ厚さの影響 については、異なる厚さのフランジを 3 種類用いた。また、スケール効 果については、積層ゴムのゴム直径が $\phi 500 \mathrm{~mm}$ と $\phi 1000 \mathrm{~mm}$ の試験 体を使用した。なお、本論文では引張面圧を負(一)で表現する。

\section{2.試験体}

図 1 に本試験に用いた試験体の外観を示す。積層ゴムはゴム部に 一体となるように加硫接着された連結鋼板を介し、ボルトにより上下フ ランジが取り付けられた構造となっている。フランジは連結鋼板を介し て積層ゴムと接合されている。ゴム直径 $\phi 500 \mathrm{~mm} 、 \phi 1000 \mathrm{~mm}$ の連結 鋼板の厚さはそれぞれ $16 \mathrm{~mm}$ と $29 \mathrm{~mm}$ である。

ゴム直径 $\phi 500 \mathrm{~mm}$ の試験体は、フランジ厚さの影響をみるため、フ ランジの厚さを $20 、 25$ および $36 \mathrm{~mm}$ の 3 種類とした。また、試験体の サイズによる特性の変化をみるための試験体として、ゴム直径 $\phi$ $1000 \mathrm{~mm}$ のものを使用した。
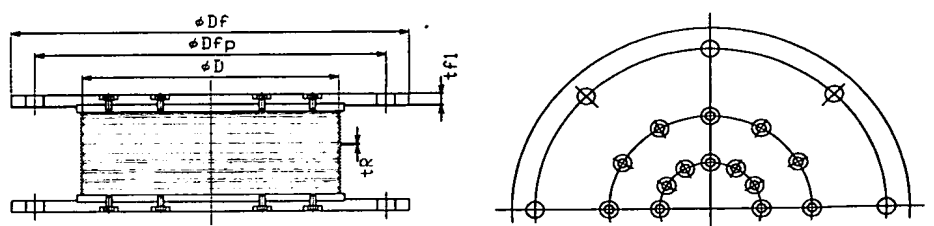

図 1 試験体外観 
$\phi 1000 \mathrm{~mm}$ のフランジ厚さは、 $36 \mathrm{~mm}$ で、 $\phi 500 \mathrm{~mm}$ のフランジ $20 \mathrm{~mm}$ の 試験体とほほ相似形となっている。

試験体として用いた積層ゴムの仕様を表 1 に示す。試験体には、 中心孔がなく、1 次形状係数 $\mathrm{S}_{1}$ は $33 、 \mathrm{~S}_{2}$ は 5.1 であり、ゴム直径 $\phi$ 500 と $\phi 1000$ の試験体は相似形状である。ゴム材料は、せん断弾性 率 $\mathrm{G} 0.44 \mathrm{~N} / \mathrm{mm}^{2}$ のものを用いた。なお、使用した試験体は、鋼板露 出型であり、被覆ゴムは取り付けられていない。

\section{表 1 試験体の仕様}

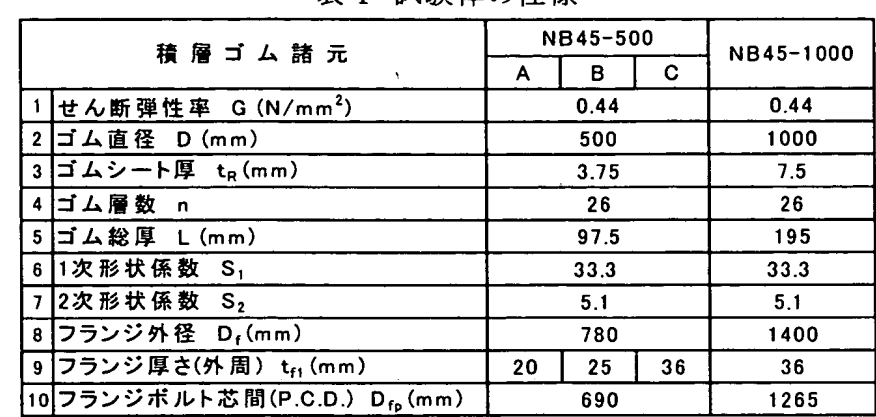

\section{3.試験方法}

(1)試験機と計測

試験機には圧縮せん断試験機を使用した。試験機の仕様は、鉛 直荷重 $15 \mathrm{MN}$ 、水平荷重 $4 \mathrm{MN}$ 、水平変位 $\pm 500 \mathrm{~mm}$ である。計測は水 平荷重、鉛直荷重、水平変位および鉛直変位を基本とした。

(2)試験条件

今回の試験は、(a)所定のせん断変形を与えた状態での、引張圧 縮試験(オフセット引張圧縮試験)、(b)鉛直方向に所定の引張ひず みまたは引張面圧を与えた状態での、せん断試験(引張せん断試験) および(c)単純引張試験を実施した。その試験載荷パターンを表 2 に 示す。引張試験前後の鉛直・水平ばね特性の変化を評価するため、 途中で基本特性の評価を実施している。

表 2 引張試験の載荷パターン

\begin{tabular}{|c|}
\hline 初期特性試験 \\
\hline 設計面圧における鉛直・水平㓮性を評価 \\
\hline$\sqrt{2}$ \\
\hline オフセット 引張一圧縮試験 \\
\hline $\begin{array}{l}\text { 所定のせん断ひずみを与えた状態で、鉛直方向に緑り返し } \\
\text { 引張一压縮変形を与えたときの鉛直剛性を評価 }\end{array}$ \\
\hline 引張せん断試験 \\
\hline 鉛直方向に所定の引張変形を与えた状態で、水平方向に \\
\hline 淥り返しせん断変形を与えたとときの水平犅性を評価 \\
\hline$\sqrt{2}$ \\
\hline 基本特性試験1 \\
\hline 微小引張経験後の設計面圧における鉛直·水平剛性を評価 \\
\hline$\sqrt{2}$ \\
\hline 単純引張試験 \\
\hline 鉛直方向に䋎り返し単純引張変形を与えたときの鉛直特性 \\
\hline を評価 \\
\hline$\sqrt{2}$ \\
\hline 基本特性試験2 \\
\hline 引張大変形経験後の設計面圧における鉛直·水平犅性を評価 \\
\hline
\end{tabular}

オフセット引張圧縮試験は、オフセットせん断ひずみ $0 、 100$ および

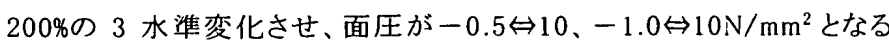
ような鉛直荷重を与えた。引張せん断試験の鉛直方向の条件につい て、面圧は $0 、-0.5$ およびー $1.0 \mathrm{~N} / \mathrm{mm}^{2}$ の 3 水準、引張ひずみは 10

と $25 \%$ の 2 水準変化させた、このとき水平方向のせん断ひずみを士 100、士200 および士250\%となる変形を与えた。ただし、ゴム直径 $\phi$ $1000 \mathrm{~mm}$ については、せん断ひずみ士200\%まででとめている。単純引 張試験は引張ひずみ $50 、 75$ および $100 \%$ 変形を与えた。各引張試 験の加力の繰り返し数は 5 回である。基本特性は設計面圧 $15 \mathrm{~N} / \mathrm{mm}^{2}$ 士 $30 \%$ となる鉛直荷重を作用させた時の鉛直剛性、および設計面圧 $15 \mathrm{~N} / \mathrm{mm}^{2}$ におけるせん断ひずみ $\pm 100 、 \pm 200$ および士250\%時の水 平剛性を求めている。基本特性については、3 回の繰り返し回数であ る。

今回の試験では、各試験におけるフランジの変形量(浮き上がり量) を測定するため、試験体を取り付けている試験機の圧盤にスリットを 設け、変位センサーを図 2 のように配置している。各サイズの試験体 のフランジ中心、フランジ中央部およびボルト固定部近傍の 3 ヶ所の 変形量を測定した。水平の加力方向は図 2 に示す矢印の方向であ る。なお、センサー位置はボルト穴を避けて加力中心から $22.5^{\circ}$ 回転 させている。

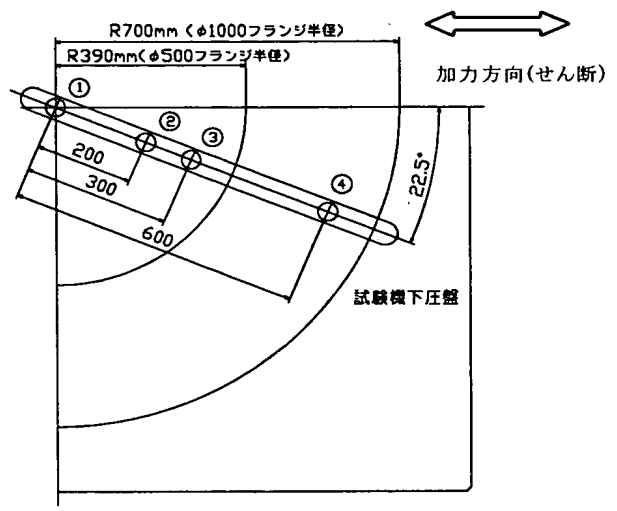

試験体 $\phi 500$ :(1)、(2)、(3) $\phi 1000$ :(1)、(3)、(4)

図 2 フランジ変形量測定ポイント

（3）特性值算出方法

各試験の鉛直・水平剛性の算出方法を図 3 に示す。特性值の算出 は、各試験において得られた最大・最小荷重值と最大・最小变位値 を用いた等価剛性により評価した。ただし、初期・基本特性の鉛直剛 性は、所定の面圧となる鉛直荷重の士30\%の範囲における荷重・変 位值を用い鉛直剛性を求めている。

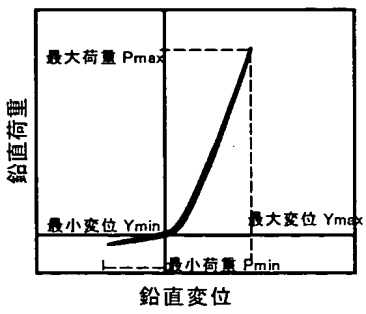

(a)压縮删性 $K^{\prime} c=P \max / \gamma_{\max }$ (b)引張渢性 $\mathrm{K} \mathrm{t}=\mathrm{P} \min / \mathrm{Y}_{\min }$

(1)引張一圧縮剛性

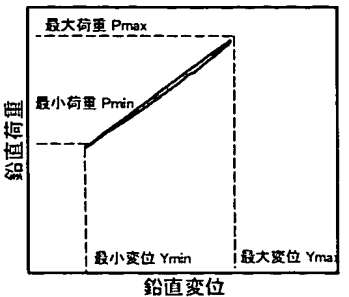

铅南到性 $K v=\left(P \max -P_{\min }\right) /\left(Y_{\max }-Y_{\min }\right)$

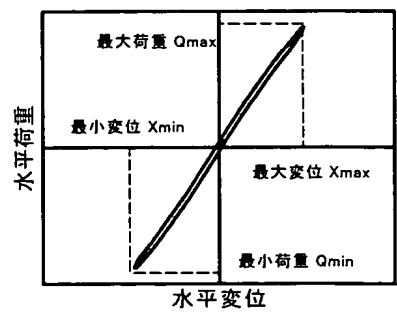

水平剧性 $\mathrm{k} h=(\mathrm{Q} \max -\mathrm{Q} \min ) /\left(\mathrm{X} \max -\mathrm{Xmin}_{\mathrm{m}}\right)$

(2)水平剛性
（3)鉛直剛性(基本)

図 3 特性值算出方法 


\section{4.試験結果}

(1)オフセット引張圧縮試験

ゴム直径 $\phi 500 \mathrm{~mm}$ 、フランジ厚さ $20 \mathrm{~mm}$ に対する試験結果を図 4 に示す。同図はオフセットせん断ひずみを $0 、 100$ および $200 \%$ と 3 水 準変化させ、面圧 $10 \sim-1.0 \mathrm{~N} / \mathrm{mm}^{2}$ 与えたときの鉛直方向の履歴曲 線である。オフセットせん断ひずみの増加とともに圧縮剛性は低下し、 引張剛性も低下していることが分かる。

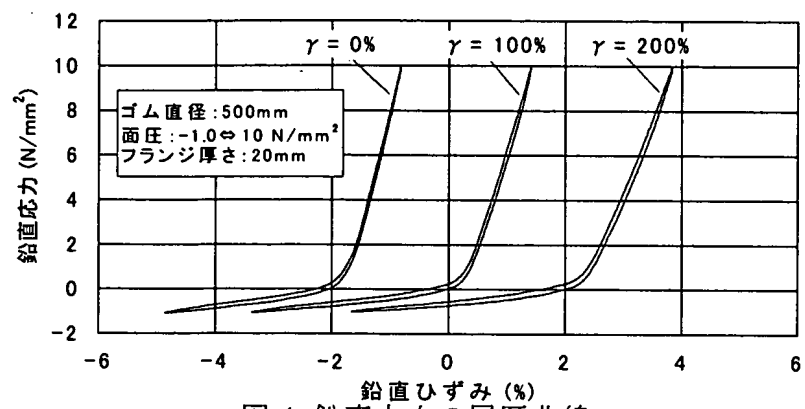

図 4 鉛直方向の履歴曲線

\section{(a)フランジ厚さの影響}

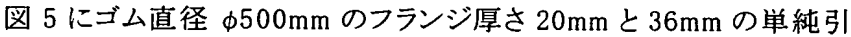
張圧縮試験から得られた鉛直方向の履歴曲線を示す。フランジ厚さ の違いにより圧縮・引張剛性が異なり、特に引張側の履歴の差が大 きい。

図 6 と図 7 にフランジ厚さと引張剛性(弾性係数に換算)の関係を 示す。フランジが厚いほど引張剛性が高くなることがわかるが、フラン ジ厚さ $20 \mathrm{~mm}$ と $25 \mathrm{~mm}$ の結果の差は小さい。面圧 $-0.5 \mathrm{~N} / \mathrm{mm}^{2}$ のとき、 フランジ厚さ $20 \mathrm{~mm}$ に対し、 $36 \mathrm{~mm}$ は 2 倍以上の引張剛性がある。し かしながら、面圧一 $1.0 \mathrm{~N} / \mathrm{mm}^{2}$ の結果はそれに比べ、差が小さくなっ ていることが分かる。これは図 8 に示すように、履歴曲線の形状から、 フランジ厚さが $36 \mathrm{~mm}$ の結果は、フランジが剛なため他の結果に比べ、 積層ゴムのゴム部の変形が降伏域に近づき剛性が低下したためと思 われる。

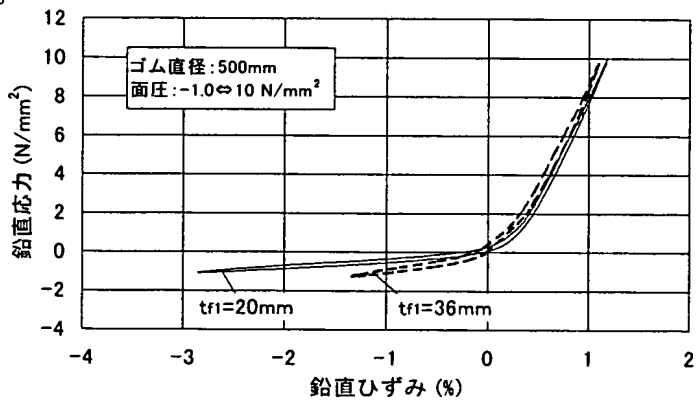

図 5 フランジ厚さの違いによる鉛直履歴特性 $(\gamma=0 \%)$

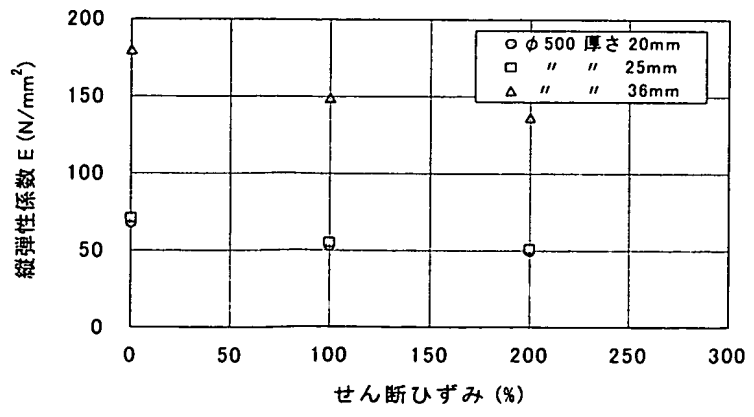

図 6 面圧 $-0.5 \mathrm{~N} / \mathrm{mm}^{2}$ のときの引張剛性

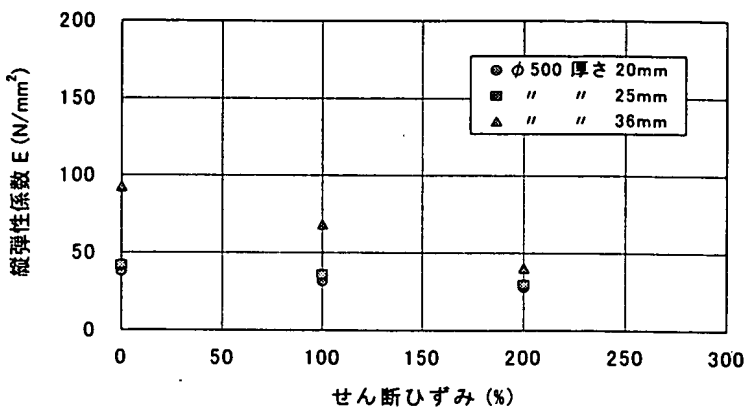

図 7 面圧 $-1.0 \mathrm{~N} / \mathrm{mm}^{2}$ のときの引張剛性

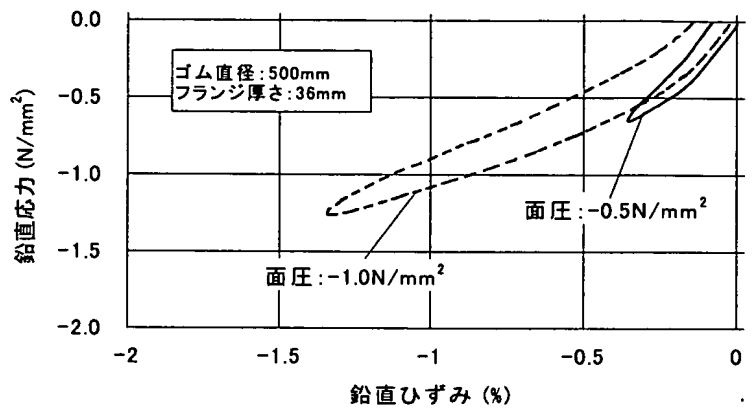

図 8 フランジ厚さ $36 \mathrm{~mm}$ の面圧による引張履歴特性の変化

\section{(b)スケールの影響}

図 9 にゴム直径 $\phi 500 \mathrm{~mm}$ と $\phi 1000 \mathrm{~mm}$ オフセットせん断ひずみ 200\%における履歷曲線を示す。両試験体の履歷曲線はほぼ一致し ていることが分かる。また、図 10 にオフセットせん断ひずみと引張剛 性の比較を示す。このときのゴム直径 $\phi 1000 \mathrm{~mm}$ の引張剛性は $\phi$ $500 \mathrm{~mm}$ に比べ、相対的に剛性が低い。これは、両試験体のフランジ や中間鋼板の仕様が完全に相似形になっていないことに起因するも のだと思われる。

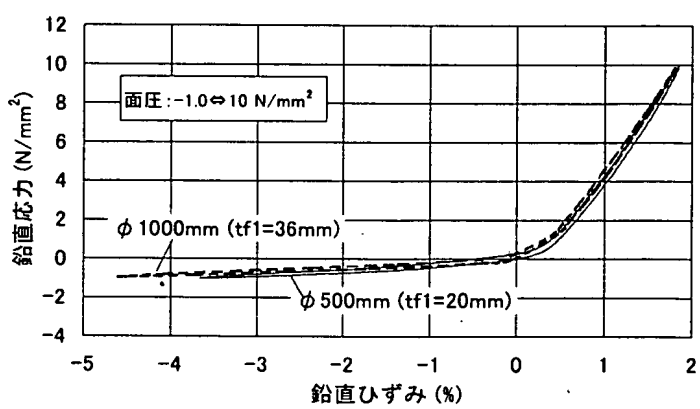

図 9 スケールの違いによる鉛直履歴特性 $(\gamma=200 \%)$

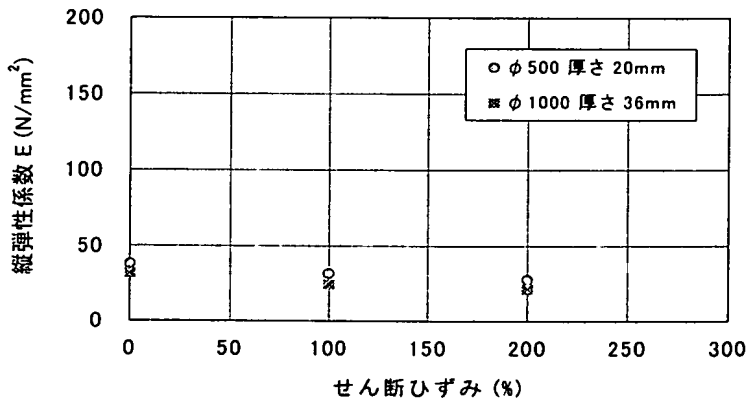

図10 スケールの違いによる引張剛性 


\section{(2)引張せん断試験}

図 11 にゴム直径 $\phi 500 \mathrm{~mm}$ フランジ厚さ $20 \mathrm{~mm}$ に対する面圧を 15 、 $0 、-0.5$ およびー $1.0 \mathrm{~N} / \mathrm{mm}^{2}$ と 4 水隻変化させ、せん断ひずみ $\gamma= \pm$ $250 \%$ 与えたときの水平方向の履歴曲線を示す。面圧 $0 \sim-1.0$ $\mathrm{N} / \mathrm{mm}^{2}$ の履歴曲線の面積は、面圧 $15 \mathrm{~N} / \mathrm{mm}^{2}$ における履歴曲線に 比べ若干小さいことが分かる。また、履歴曲線の形状についてみると、 面圧一 $1.0 \mathrm{~N} / \mathrm{mm}^{2}$ の曲線は他の条件に比べ、やや直線状になって いる。図 12 に引張ひずみを 2 水隻変化させ、せん断ひずみ $\gamma= \pm$ $250 \%$ 与えたときの水平方向の履歷曲線を示す。それぞれの履歴曲 線は面圧 -0.5 とー $1.0 \mathrm{~N} / \mathrm{mm}^{2}$ に対する履歷曲線とほぼ同じ形状で ある。

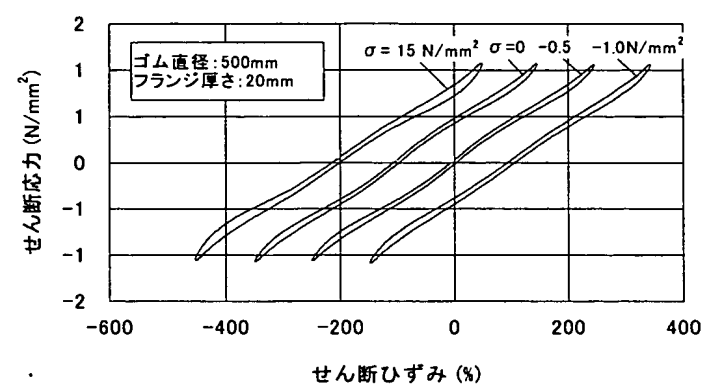

図 11 一定の引張面圧を与えたときの水平履歴特性

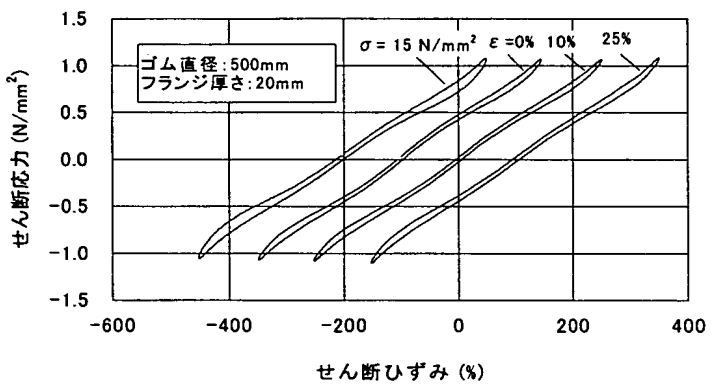

図 12 一定の引張ひずみを与えたときの水平履歴特性

\section{（a）フランジ厚さの影響}

図 13 と図 14 にそれぞれ、フランジ厚さ $20 \mathrm{~mm}$ と $36 \mathrm{~mm}$ の面圧一 $1.0 \mathrm{~N} / \mathrm{mm}^{2}$ 、せん断ひずみ士250\%の時の引張せん断試験で得られた 履歷特性を示す。水平履歷と鉛直ひずみともに良い一致を示してい る。図 15 に引張面圧を作用させたときのフランジ厚さごとの水平剛性 (せん断弾性率に換算)のひずみ依存性を示す。水平剛性はフランジ 厚さに影響を受けないことが分かる。また、面圧 $-1.0 \mathrm{~N} / \mathrm{mm}^{2}$ のとき、 鉛直方向に約 $25 \%$ のずみを生じているため、水平剛性は面圧 $15 \mathrm{~N} / \mathrm{mm}^{2}$ のときに比べ若干上昇するが、大きくは変化しない。

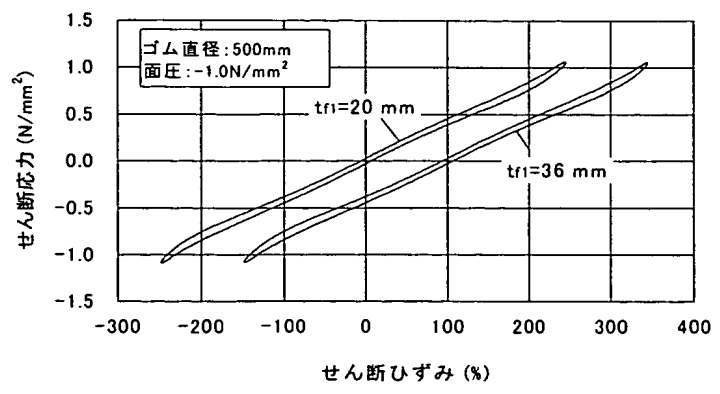

図 13 フランジ厚さの違いによる水平履歴特性

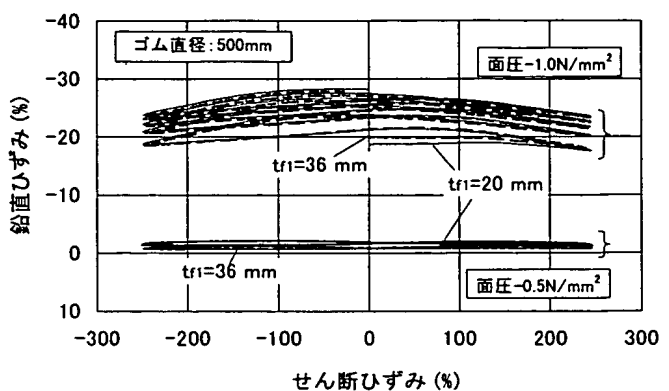

図 14 フランジ厚さの違いによる鉛直履歴特性

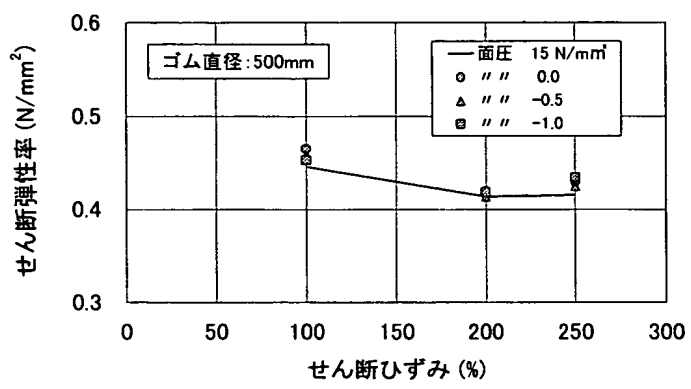

(a)フランジ厚さ $20 \mathrm{~mm}$

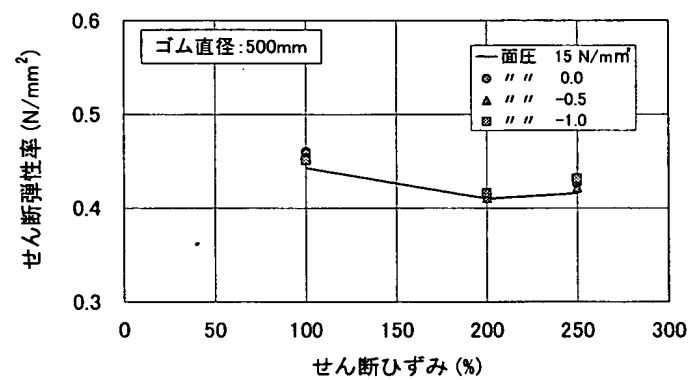

(b)フランジ厚さ $36 \mathrm{~mm}$

図 15 フランジ厚さの違いによる水平剛性の変化

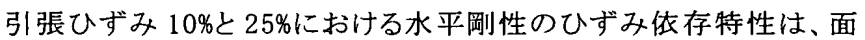
圧一 0.5 とー $1.0 \mathrm{~N} / \mathrm{mm}^{2}$ のときと同等の特性を示す。特に、面圧一 $1: 0 \mathrm{~N} / \mathrm{mm}^{2}$ の鉛直ひずみは $25 \%$ に相当することから、水平剛性もほぼ 同値であった。

(b)スケールの影響

図 16 と図 17 に面圧 $-1.0 \mathrm{~N} / \mathrm{mm}^{2}$ 、せん断ひずみ $\pm 200 \%$ ときの、 引張せん断試験結果を示す。水平方向の履歴特性はほぼサイズに よらず一致している。鈶直ひずみの履歷曲線は、やや異なる性状を 示しているが、鉛直ひずみの大きさはほぼ同等である。図 18 に面圧 を変化させたときのひずみ依存特性を示す。このときの結果は、図 15 に示すゴム直径 $\phi 500 \mathrm{~mm}$ の結果と同じ傾向にあり、水平剛性につい ては、スケールの影響は小さいものと考えられる。

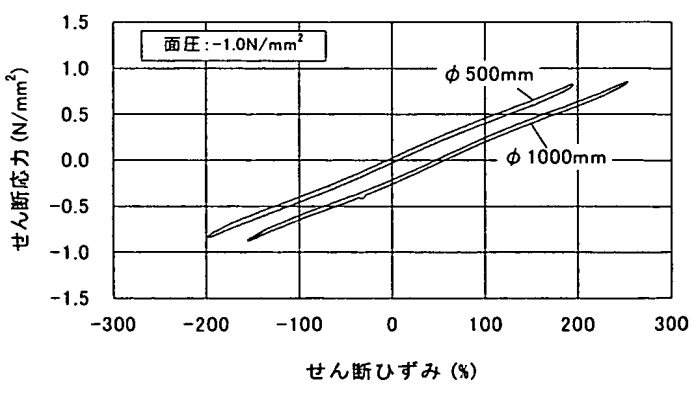

図 16 スケールの違いによる水平履歴特性 


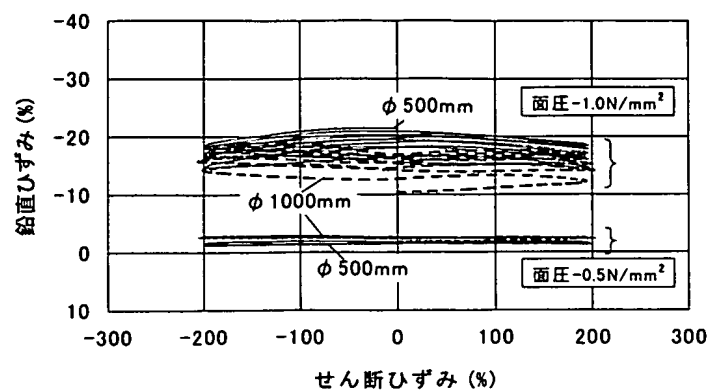

図17 スケールの違いによる鉛直履歴特性

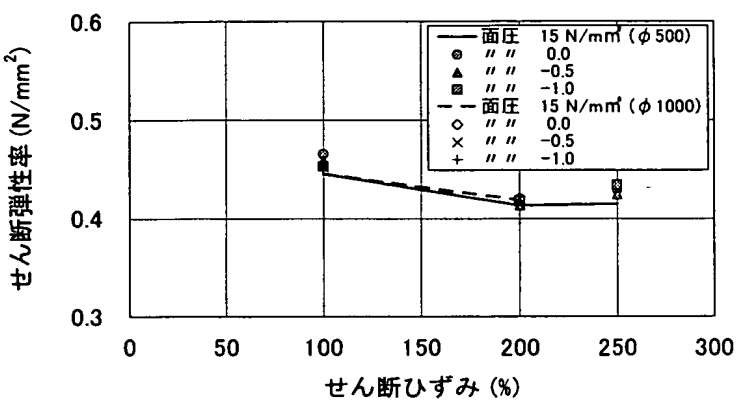

図 18 スケールの違いによる水平剛性

(3)単純引張試験

(a) フランジ厚さの影響

図 19 にゴム直径 $500 \mathrm{~mm}$ の異なるフランジ厚さの単純引張試験で 得られる1サイクルと 5 サイクル目の履歷特性を示す。変形の小さいと ころではフランジ厚さの影響を受けているが、変形の大きいところでは、 履歴曲線はほぼ一致していることが分かる。このことから、引張変形 の大きいところでは積層ゴムのゴム部の変形が支配的になり、フラン ジ厚さの影響が小さくなっていることが分かる。

(b)スケールの影響

図 20 に、異なるサイズの単純引張試験について、変形の小さい領 域、大きい領域ともに履歴曲線が若干異なっている。フランジ厚さは ほぼ相似形状だが、中間鋼板その他の仕様が完全な相似形ではな いことに起因すると思われる。

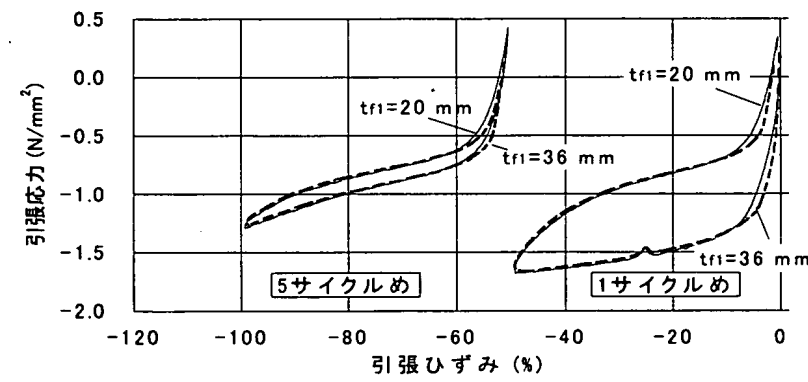

図 19 フランジ厚さの違いによる引張大変形特性

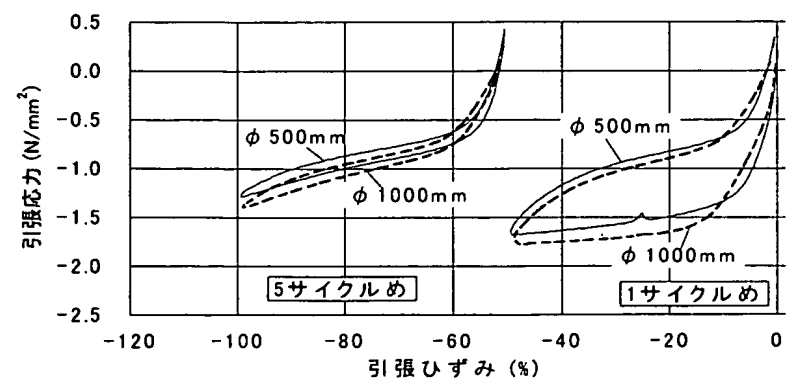

図 20 スケールの違いによる引張大変形特性
(4)引張経験前後の基本特性変化

図 21 と図 22 に異なるフランジ厚さとサイズの引張前後の基本特性 の変化を示す。鉛直剛性については、若千の変動が見られるが、水 平剛性についての変動は非常に小さいことが分かる。フランジ厚さ、 スケールの影響も小さいと思われる。

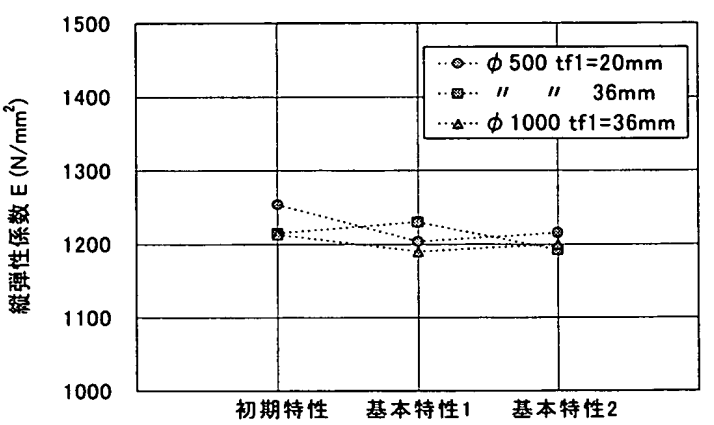

図 21 基本特性試験での鉛直剛性の変化

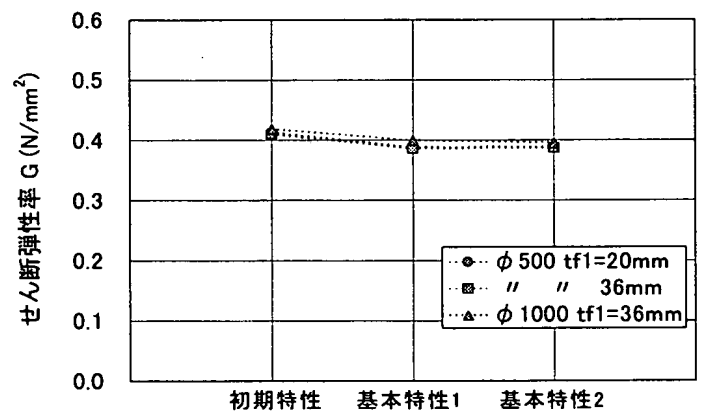

図 22 基本特性試験での水平剛性の変化 $(\gamma= \pm 200 \%)$

(5)フランジの変形の検討

図 23 にオフセット引張圧縮試験結果で得られるフランジ中心、中 央部およびボルト近傍のフランジ変形量を示す。最大変形はフランジ 中心で、外周に向かって変形量は小さくなっている。

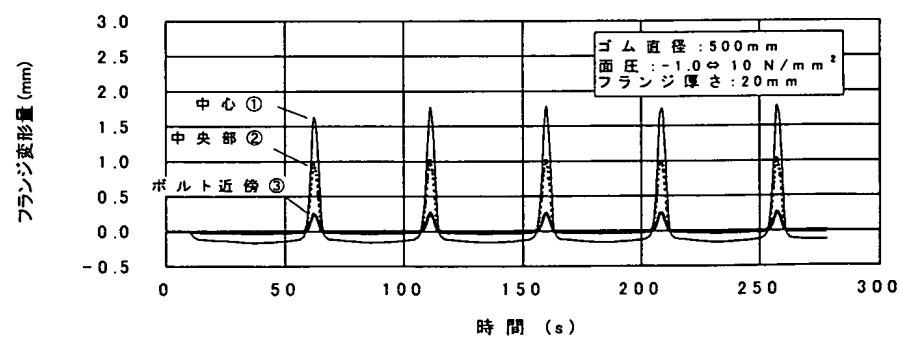

図 23 フランジの変形量と時間関係

フランジを単純な円板と仮定し、周辺は単純支持、同心円(連結銅 板部分)に等分布荷重 $\mathrm{p}$ が作用しているモデルを考えると、フランジの 面外変形量は次式で与えられる。

$0 \leqq \mathrm{r} \leqq \mathrm{b}$ のとき

$\delta=\frac{p b^{4}}{16 D}\left[\frac{r^{4}}{4 b^{4}}-\frac{4 a^{2}-(1-v) b^{2}}{2(1+v) a^{2}}\left(\frac{r}{b}\right)^{2}-\left(2 \frac{r^{2}}{b^{2}}+1\right) \ln \frac{b}{a}+\frac{4(3+v) a^{2}-(7+3 v) b^{2}}{4(1+v) b^{2}}\right]$ 
$\mathrm{b} \leqq \mathrm{r} \leqq \mathrm{a}$ のとき

$\delta=\frac{p b^{4}}{16 D}\left[\frac{1}{2(1+v)}\left(1-\frac{r^{2}}{a^{2}}\right)\left\{2(3+v) \frac{a^{2}}{b^{2}}-(1-v)\right\}-\left(1+\frac{2 r^{2}}{b^{2}}\right) \ln \frac{a}{r}\right]$

ここで $\mathrm{D}=\mathrm{Eh}^{3} /\left\{12\left(1-v^{2}\right)\right\} 、 \mathrm{E}:$ ヤング率、v:ポアンン比、h : 板厚、 $\mathrm{a}:$ ボルトとフランジ中心の距離および $\mathrm{b}:$ 連結鋼板半径である。

図 24 に異なるフランジ厚さの変形量(理論値)と実測値を示す。実 測值に比べ、理論値が大きいことが分かる。そこで、連結鋼板のフラ ンジの上側に出ている部分(高さ $\mathrm{tr}$ ') の体積をフランジ円周方向に均 等に振り分けた”等価なフランジ厚さ”により理論值を計算した。その ときの等価フランジ厚さの增分 $\Delta \mathrm{t}$ は次式で与えられる。

$\Delta t=\left(\frac{D_{r}}{D_{f p}}\right)^{2} t_{r}^{\prime}$

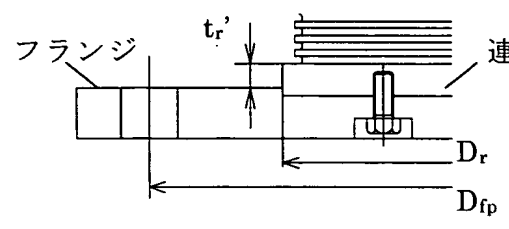

連結鋼板

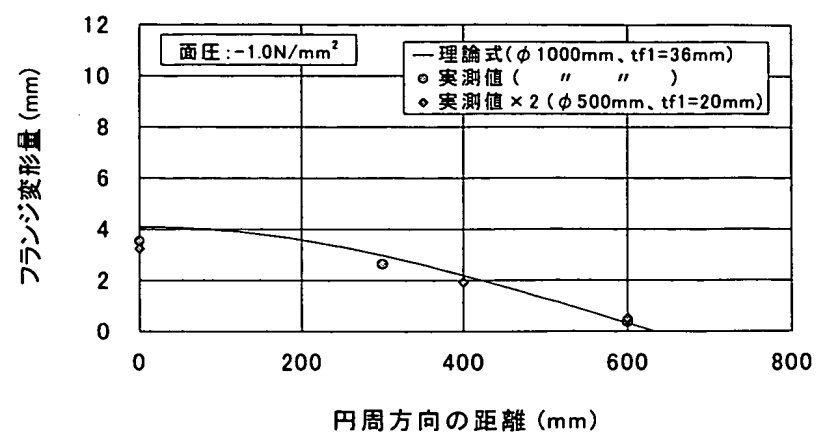

図 26 連結鋼板を考虑したフランジの恋形(ゴム直径 $\phi 1000)$

\begin{tabular}{|c|c|c|c|c|c|}
\hline $\begin{array}{c}\text { フランジ咠さ } \\
\mathrm{mm}\end{array}$ & $\begin{array}{c}\text { 全体の引張㓮性 } \\
\mathrm{MN} / \mathrm{m}\end{array}$ & $\begin{array}{c}\text { フラシシ変形の } \\
\text { 平均値 mm }\end{array}$ & $\begin{array}{c}\text { 纷直荷重 } \\
\mathrm{kN}\end{array}$ & $\begin{array}{c}\text { フランジの捱惟 } \\
\mathrm{MN} / \mathrm{m}\end{array}$ & $\begin{array}{c}\text { 皘層ゴムの明性 } \\
\mathrm{MN} / \mathrm{m}\end{array}$ \\
\hline 20 & 84 & 0.18 & 102 & 300 & 193 \\
\hline 25 & 81 & 0.15 & 103 & 438 & 130 \\
\hline 36 & 129 & 0.07 & 127 & 2318 & 146 \\
\hline
\end{tabular}

ため、見かけの剛性ではあるが、ある一定値に収束する傾向にあるこ とが分かる。

ここで、 $D_{\mathrm{r}}$ : 連結鋼板直径、 $\mathrm{D}_{\mathrm{fp}}$ : フランジボルト PCD である。ゴム直径 $\phi 500 \mathrm{~mm}$ と $\phi 1000 \mathrm{~mm}$ の $\mathrm{tr}^{\prime}$ は、それぞれ 12 と $20 \mathrm{~mm}$ である。

板厚 $\mathrm{h}$ を式(3)を考虑して厚くした結果を図 25 に示す。各フランジ 位置での変形量の大きさと円周方向の変形量の分布もよく一致して いることが分かる。図 26 にゴム直径 $\phi 1000 \mathrm{~mm}$ の結果と $\phi 500 \mathrm{~mm}$ の 実測値をスケール倍(2 倍)したときの值を示す。各実測値とも理論值 に良い一致を示す。このことから、等価なフランジ厚さを考慮すること でフランジの変形を模擬できることが分かり、スケール則も適用可能 であると思われる。

フランジと積層ゴムを単純な直列ばねと仮定し、実測したフランジ変 形量から、積層ゴム本体(フランジを除く)の引張剛性を求めることにし た。フランジの変形量はフランジ中心とフランジ中央部の平均值を用 いた。その結果を表 3 に示す。積層ゴムは均一に引張られていない

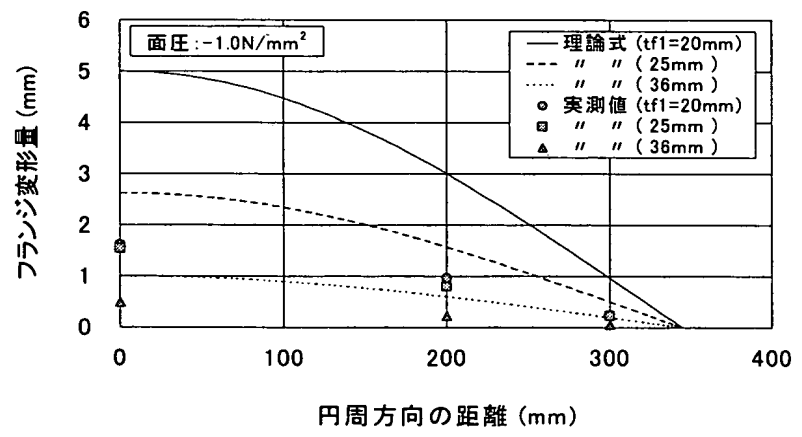

図 24 面圧一 $1.0 \mathrm{~N} / \mathrm{mm}^{2}$ におけるフランジの変形(ت゙ム直径 $\left.\phi 500\right)$

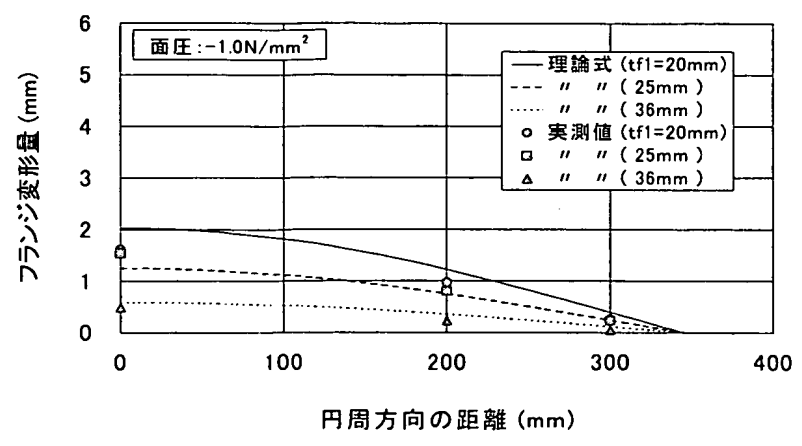

図 25 連結鋼板を考虑したフランジの変形(ゴム直径 $\phi 500)$

\section{5.まとめ}

天然ゴム系積層ゴムについて、引張試験を実施し、フランジ厚さとス ケールの影響およびフランジの変形について検討し、以下の結果が 得られた。

(1)オフセットせん断引張一圧縮試験により得られた結果から、引張 剛性はフランジの厚みに対し敏感であることがわかった。

(2)引張せん断試験では、引張面圧 $-1.0 \mathrm{~N} / \mathrm{mm}^{2}$ で鉛直方向に積層 ゴムが伸びあがっていく傾向がある(引張せん断時の鉛直ひずみで 10〜20\%に相当)が、水平剛性に及ぼす影響は小さい。また水平剛 性はフランジの厚みには影響されない。

（3）ゴム直径 $\phi 500 \mathrm{~mm}$ と $\phi 1000 \mathrm{~mm}$ の試験結果から、微小引張領域 の特性は概ね一致することが分かった。

(4)オフセットせん断引張一圧縮試験、単純引張試験の結果からフラ ンジが厚いほど弾性勾配が大きくなることから、フランジがある程度 薄いほうが積層ゴム本体への影響が小さいと考えられる。ただ、ど の程度まで薄くすることが可能であるかは積層ゴムの局部ひずみ や局部応力に着目した検討が必要であろう。

(5)引張経験後の基本特性(鉛直・水平剛性)は、保持される。

(6)フランジ変形量は、等価なフランジ厚さを考慮することで簡単なモ デルを用いて推定可能である。

今後、フランジの引張変形について、積層ゴムの詳細な仕様を取り 入れた FEM 解析などを実施することにより、フランジの設計法の提案 が可能であると考える。

(参考文献)

1)小崎, 藤田他: 超高層免霞建物に適用する天然系積層ゴムに関する 研究, 日本建築学会大会学術講演梗概集,pp639-pp640,2000

2)Gent, A.N. : Elastic Stability of Rubber Compression Springs, Journal Mechanical Engineering Science,pp318-pp 326,1964 3)高山：免震構造用天然ゴム系樌層ゴムアイソレータの限界特性, 日本建築学会技術報告集, pp160-pp165, 1995

4)大鳥: 積層ゴム免震要素の引張許容応力設定に関する検討, 日本建 築学会大会学術講演梗概集,pp535-pp536,1997

[2001年10月19日原稿受理 2002年 2 月18日採用決定］ 